\title{
LAKATOS MÁTÉ
}

\section{A befektetői túlreagálás empirikus vizsgálata a Budapesti Értéktőzsdén}

\begin{abstract}
A tanulmány egy lokális és relatíve kis tőkepiacon, a Budapesti Értéktőzsdén teszteli a viselkedési pénzügyek azon állítását, hogy a befektetők túlreagálják a piacon elérhető információkat. Elsőként a reverziós jelenséget vizsgálja meg a tanulmány, amely kimondja, hogy a befektetési túlreagálás következtében a múltban a piacot alulteljesítő részvények a jövőben szignifikánsan felülteljesítővé válnak, és fordítva. Az eredmények alapján nem lehet elutasítani, hogy a Budapesti Értéktőzsdén megfigyelhető a túlreagálási jelenség, ami statisztikailag is szignifikánsnak bizonyul. A tanulmány további célja a reverziós jelenség, illetve a lendülethatás közötti kapcsolat elemzése, valamint ezen anomáliák hosszára vonatkozó vizsgálat. A számítások alapján elmondható, hogy leginkább a vizsgált befektetési időhorizonttól függ az anomáliák jelenléte. Rövid, éven belüli időtávon kitart a portfóliók lendülete, azonban egy éven túli perióduson továbbra is elfogadható a reverziós jelenség, amely a kiértékelési időtáv vége felé fokozatosan megszünik.* Journal of Economic Literature (JEL) kód: G02, G12, G14, C58, C12.
\end{abstract}

A piacok hatékonyságára vonatkozó állítás, amely kimondja, hogy az értékpapírok árai hüen tükrözik a megjelent információkat, meglehetősen réginek mondható, már a 20. század legelején születtek erre vonatkozó kijelentések. Kissé más formában ugyan („fair játszma”) és nem explicit módon, de megjelent Bachelier [1900] múlt század eleji doktori értekezésében is a piaci hatékonyság fogalma, amely kétségtelenül Fama [1970] mérföldkőnek számító cikkével vált ismertté a pénzügyi közgazdaságtanban, és maga a hatékony piacok elmélete (Efficient Market Theory) is Fama nevéhez kötődik. A hatékony piacok elmélete jól tesztelhető predikciókat kínál a részvények áralakulására vonatkozóan, így a viselkedési pénzügyek számos tanulmánya vizsgálta az elmélet gyakorlati teljesülését. Barberis-Thaler [2003] strukturáltan foglalta össze a hatékony piacok elméletét cáfoló lehetséges magyarázatokat,

\footnotetext{
* Köszönettel tartozom Kiss Hubert Jánosnak, aki tanácsaival, megjegyzéseivel, kritikájával nagyban hozzásegített a cikk elkészítéséhez. Köszönöm továbbá a két anonim bíráló építő megjegyzéseit. A tanulmány a PADS Alapítvány anyagi támogatásával valósult meg.
}

Lakatos Máté közgazdász-biztosítási és pénzügyi matematikus (mate.lakatos@outlook.com). A kézirat első változata 2015. június 19-én érkezett szerkesztőségünkbe.

DOI: http://dx.doi.org/10.18414/KSZ.2016.7-8.762 
amelyek a viselkedési pénzügyek mint tudományterület fő motivációját jelentik egyben. A viselkedési pénzügyek legfőbb célja tehát, hogy a pszichológiai állításokat felhasználva kiegészítse az általános modelleket, növelje azok magyarázóerejét, gyakorlati felhasználhatóságát (Camerer és szerzőtársai [2004]). ${ }^{1}$

A piaci hatékonyság megkérdőjelezésében mérföldkőnek számít De Bondt-Thaler [1985] eredménye, amelynek értelmében az egyéni pszichológiai tényező a piacon elérhető információk túlreagálásában nyilvánul meg. Így a befektetői túlreagálási hipotézis értelmében, ha a befektetők túlértékelik a múltbeli teljesítményt, akkor a magas hozamú részvények szükségképpen túlárazottá válnak bizonyos idő elteltével, aminek a jövőben korrigálódnia kell, tehát várhatóan csökken majd az áruk, s így hozamuk negatív lesz. Más szóval élve, egyfajta reverziós jelenség figyelhető meg a részvénypiacokon, azaz a múltban a piacot alulteljesítő részvények a jövőben túlteljesítik a piacot, és vice versa. Nagyban kapcsolódik a reverziós jelenséghez a lendülethatás (momentum effect), amely mondhatni a reverziós jelenségnek mint anomáliának az ellenpárja. A lendülethatás értelmében - amelyet elsőként Jegadeesh-Titman [1993] írt le - a múltban a piacot felülteljesítő részvények továbbra is felülteljesítik a piacot, az alulteljesítők pedig továbbra is alulteljesítenek, azaz kitart a részvények „lendülete”.

Az irodalmi áttekintés után az alkalmazott módszertant ismertetjük, melynek segítségével a tanulmány elsőként teszteli a befektetői túlreagálást a Budapesti Értéktőzsdén. Az eddigiekben meglehetősen kevés viselkedési pénzügyi témájú tanulmány készült az európai piacokon végzett empirikus eredmények alapján, a nemzetközi irodalom legnagyobb része az amerikai értékpapírpiac valamely tőzsdéjének részvényein keresztül tesz kísérletet az anomáliák igazolására. A jelen tanulmány ugyanakkor egy alacsony kapitalizációjú piaccal vizsgálja a túlreagálási jelenséget, köszönhetően a hazai tőzsde relatíve kis méretének. Így a tanulmány nem próbál általános érvényű következtetéseket levonni, sokkal inkább azt vizsgálja, hogy egy nagy és likvid piacon észlelt anomália teljesül-e egy lokális és méretéből fakadóan kevésbé likvid piacon.

Összességében elmondható, hogy az eredmények alátámasztják a befektetői túlreagálási jelenséget a Budapesti Értéktőzsdén, hosszú távon teljesül a reverzió, azaz a piacot alul(túl)teljesítő portfólió a következő időszakban felül(alul)teljesíti a piacot. Ezen eredmény statisztikai értelemben is helytálló marad, valamint robusztus az abnormális hozam különböző számítására nézve is.

A tanulmány további célja annak vizsgálata, hogy a reverziós jelenség elfogadása vagy elvetése mennyiben és milyen módon függ a választott kiértékelési intervallum hosszától. Másképp fogalmazva: teljesül-e az az állítás, hogy a reverziós jelenség csak hosszabb befektetési időhorizonton figyelhető meg, ezáltal a kontrariánus stratégia hosszabb távon érvényesülhet. Másik oldalról pedig igaz-e az, hogy rövid időtávon inkább a lendülethatás érvényesül, valamint mit mondhatunk e két jelenség közötti kapcsolatról, az esetleges átmenetröl. Kérdés tehát, hogy lehet-e találni valamilyen szignifikáns kapcsolatot a befektetési időhorizont, illetve a lendület- és

\footnotetext{
${ }^{1}$ A viselkedési pénzügyeknek számos befektetői és egyéb döntéshez kapcsolódó anomáliája létezik még a túlreagálás mellett (lásd például Komáromi [2002], Barberis-Thaler [2003], Shiller [2003], Molnár [2006a] vagy Della Vigna [2009]), azonban ezek rendszerezése nem célja a tanulmánynak.
} 
a kontrariánus stratégia elméleti jövedelmezősége között. Az eddigiekben a témában megjelent eredmények rendszerint a reverzió vagy a lendület létezését vizsgálták, ugyanakkor kevésbé elemezték a reverzió és lendület közötti kapcsolat, a két jelenség közötti átmenet mikéntjét. Vayanos-Woolley [2013], illetve McLean [2010] számításaik során felfigyelnek ugyan a két jelenség létezésére, azonban mindkét tanulmány alapjaiban más céllal készült, azaz jelenleg nem ismert olyan elemzés, amely az említett kérdést szisztematikusan vizsgálná globális vagy éppen regionális piaci adatokra vonatkozóan.

Ebben a tekintetben az eredmények alapján az a következtetés vonható le, hogy a legalább másfél év hosszúságú intervallum választása esetén szignifikánsan elfogadható a reverziós jelenség, az egy éven belüli periódusoknál ugyanakkor kitart a portfóliók lendülete, azaz a korábban túl(alul)teljesítő részvények továbbra is túl(alul) teljesítik a piacot. A tanulmány további megállapítása, hogy leginkább a periódus hosszától függ a reverzió és a lendülethatás bekövetkezése. Végül kitérek a mérethatás („size effect”) szerepére és megvizsgálom, hogy az miként befolyásolja az eredmények alakulását. A mérethatás jelenléte némileg árnyalja ugyan a kapott eredményt, de nem változtatja meg az elemzés állításait. A legtöbb esetben valamilyen irányú szignifikáns eltérés rendszerint adódik a vizsgált részvények tekintetében (túl- vagy alulteljesítés), így a piaci hatékonyság nem teljesül a Budapesti Értéktőzsdén, s leginkább az említett anomáliák állnak a háttérben. Az eredmények összegzését a további lehetséges kutatási irányok bemutatása követi.

\section{Irodalmi áttekintés}

A befektetôi túlreagálással kapcsolatosan számos elemzés látott napvilágot a múltban, s meglehetősen éles vita övezi a túlreagálási jelenség létezését, elfogadását. Ennek megfelelően elsőként a befektetői túlreagálással és piaci hatékonysággal foglalkozó eredményeket mutatjuk be, kitérve a magyar piacon elvégzett elemzésekre is.

A túlreagálással kapcsolatban De Bondt-Thaler [1985] mérföldkőnek számító elemzésében arra a következtetésre jut, hogy a múltban rosszul teljesítő részvények a jövőben 25 százalékkal „megverik” a korábban jól teljesített részvényeket. A szerzőpáros különböző, egymást nem átfedő időszakokban (megfigyelési periódus) választotta ki mind a piacot alulteljesítő, mind pedig a piacot túlteljesítő részvényeket, amelyekből egy-egy portfóliót képezve vizsgálta azok teljesítményét az elkövetkezendő években (tesztperiódus). Átlagolva a megfigyelési periódusok túlés alulteljesítő portfólióinak hozamát, a szerzőpáros azt kapta eredményül, hogy a megfigyelési periódusban alulteljesítő portfóliók szignifikánsan jobb eredményt értek el a túlteljesítő portfólióknál (1. ábra).

A túlreagálási jelenségen túl - amely aszimmetrikus abban az értelemben, hogy a vesztes portfólió esetén erősebb a reverzió - a szerzők azonosították a januárhatás (january effect) jelenségét is, amely szerint az abnormális hozamok januárban kiemelkednek, ahogy az ábrán is látható (1., 13., 25. hónap jelöli a januári hónapokat). Ezzel kapcsolatban a szerzők hasonló eredményre jutottak későbbi elemzéseik során is (De Bondt-Thaler [1987]). 
1. ábra

A győztes és vesztes portfóliók kumulált abnormális hozamai (CAR) a tesztperiódusban (1-36 hónap)

CAR (kumulált abnormális hozam)

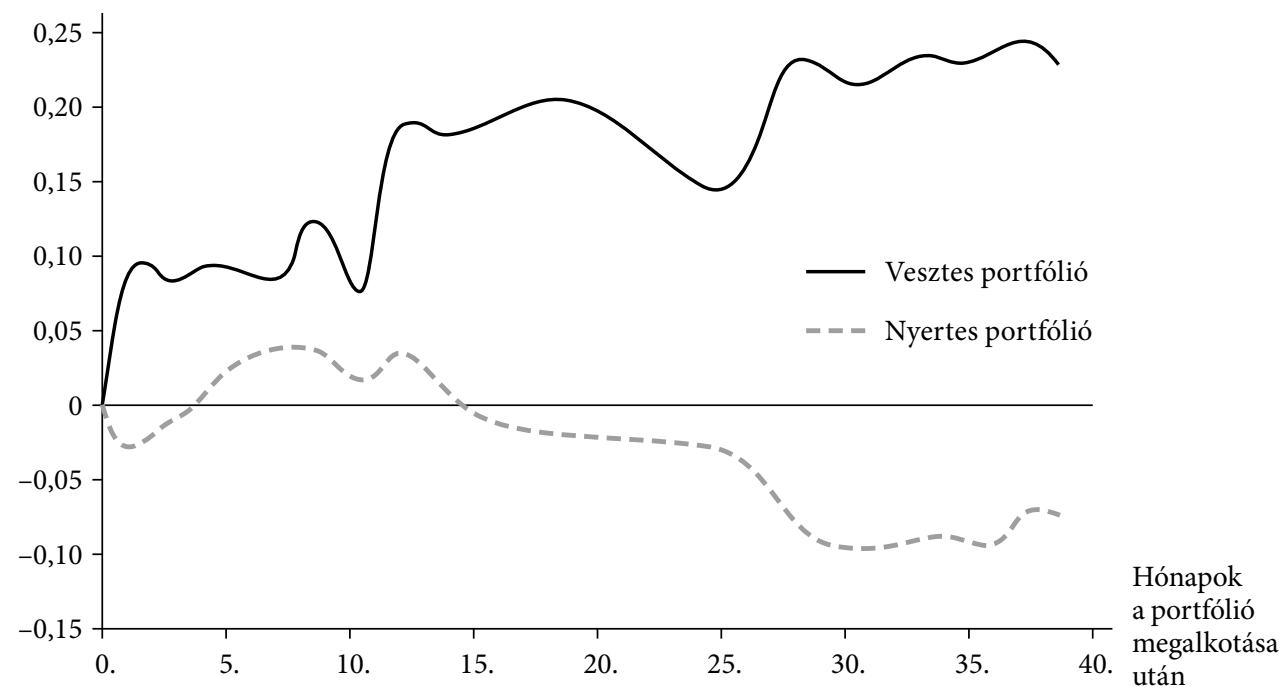

Forrás: De Bondt-Thaler [1985].

Maga az eredmény, illetve az ebböl származó következtetés, a túlreagálási hipotézis elfogadása ugyanakkor megcáfolta Fama [1970] - a piaci hatékonyság létezéséről közölt - cikkének eredményét, amire reagálva Fama [1991] további érveket és eredményeket hozott a piac hatékonysága mellett. Részben ezen eredmények alapján született a Fama-French-féle háromtényezős modell (Fama-French [1996]), majd egy évvel később Carhart [1997] négytényezős modellje, amelyek a tökepiaci árfolyamok modelljébe (capital asset pricing model, CAPM) további magyarázókat emelnek be, csökkentve ezáltal a hozamok varianciájának meg nem magyarázott részét, azaz a reziduumokban maradó információt.

De Bondt-Thaler [1985] eredményét elfogadja Zarovin [1989], azonban a cikk következtetését meglehetősen élesen támadja. Elemzésében bemutatja, hogy a nyertes és vesztes portfóliók tesztperiódusbeli teljesítménye leginkább a mérethatástól függ, hiszen azonos méretű vállalatok esetén a különbség jóval szerényebb a két portfólió esetében. Ezzel pedig határozottan elutasítja a túlreagálási jelenséget. A mérethatást igazolja Chopra és szerzőtársai [1992] elemzése is, de a befektetői túlreagálást is szignifikánsnak találja, azaz De Bondt-Thaler [1985] eredménye mellett érvel. Chan [1988], valamint Ball-Kothari [1989] szintén igazolja a vesztes és nyertes portfólió létét, azonban megállapítja, hogy az okok nem a túlreagálásra vezethetők vissza.

Az elözőkben számba vett eredmények kivétel nélkül a túlreagálási jelenségből levonható következtetések helytállóságának cáfolására vagy alátámasztására vonatkoztak. A témában megjelent elemzéseknek egy másik csoportját alkotják azok az eredmények, amelyek a reverzióra vonatkozó eredmények robusztusságát 
kérdőjelezik meg abban az értelemben, hogy az valóban bekövetkezik-e. Ezzel kapcsolatban Chen-Sauer [1997] arra az eredményre jut, hogy a De Bondt-Thaler [1985] által vizsgált időszak nem minden periódusában teljesül a reverzió, azaz léteznek olyan évtizedek, amelyek során az összefüggés nem szignifikáns. Barberis és szerzötársai [1998] szintén a befektetőket vizsgálta a helytelen bayesi becslés miatt, azonban más megközelítéssel érvelt. A szerzők szerint a „kis számok törvénye” miatt jelen esetben egy valójában sztochasztikus folyamatról az egyének azt hiszik, hogy két kimenetel lehetséges, az átlaghoz való visszatérés (mean reverting) vagy a trend folytatása (trending). A cikk állítása szerint a közelmúltbeli információk alapján az egyének az átlaghoz való visszahúzást vélik valószínủbb kimenetelnek, ami alapján viszont rövid távon pozitív a kapcsolat a két (megfigyelési és teszt-) periódus között, mivel az egyének alulreagálják az információkat.

Szintén ezt az állítást támasztja alá Jegadeesh-Titman [1993] eredménye: a szerzők ugyan nem viselkedési szempontból közelítették meg az anomáliát, csupán egy „jól teljesítö" kereskedési stratégiát próbáltak felállítani. Az előző hat hónap alapján nyertes portfóliók további hat hónapos tartásával 12 százalékos többlethozamot értek el. Eredményük szerint tehát a megfigyelési periódusban túl-, illetve alulteljesítő portfóliók a tesztperiódusban is hasonlóan teljesítenek, azonban - igazolva ezzel az előbbi állítást - a pozitív kapcsolat csökken, majd negatívba megy át. Megállapítják továbbá, hogy a későbbi hónapokban már kevésbé szignifikánsak az adatok. Ahogyan a bevezetőben is volt róla szó, a reverziós jelenség - mint anomália - ellenpárjaként tekinthetünk a Jedadeesh-Titman [1993] által ismertetett lendülethatásra, hiszen azok alapjaiban mondanak ellent egymásnak.

De Bondt-Thaler [1985] eredménye szerint ugyanis a különbség éppen a későbbi időszakban szignifikáns a két portfólió között, valamint az sem tisztázott, hogy a korai szakaszban eltérő eredményt kaptak. Továbbá Jegadeesh-Titman [1993] szigorúan leszögezi, hogy ebből az eredményből egyáltalán nem lehet következtetni viselkedési anomáliákra, hiszen nem lehetünk teljesen biztosak abban, hogy miért történik meg a jelenség, csupán egy anomáliát találtak, amely jelen esetben ellentmond egy korábbi anomáliának, s amelyet De Bondt-Thaler [1985] a befektetői túlreagálásra vezetett vissza. Söt Jegadeesh-Titman [1993] többször tesz utalást De Bondt-Thaler [1985] eredményéből levont következtetés megkérdőjelezésére, miszerint csupán a mérethatás és a két ellentétes portfólió szisztematikus kockázata miatt jutottak erre az eredményre, és nem pedig a túlreagálás áll az eredmény mögött. Ennek hangsúlyozására Jegadeesh-Titman [1993] hivatkozik több, részben ezen irodalmi áttekintésben is szereplő eredményre, amelyek ugyancsak a befektetői túlreagálást támadják. Mindazonáltal Jegadeesh-Titman [1993] eredményének jelentősége megkérdőjelezhetetlen, egy ellentétes anomália (lendülethatás) kimondása mellett felhívták a figyelmet arra, hogy egyrészt az anomáliák egymással szemben állva is létezhetnek, másrészt pedig az anomáliát is sokféleképpen lehet megmagyarázni.

Ahogy a tanulmány bevezetője is hangsúlyozta, az eddigiekben meglehetősen kevés kutatás vizsgálta együtt a két jelenséget. Vayanos-Woolley [2013] magyarázatot keresve a reverziós jelenség és a lendülethatás okaira, együtt vizsgálja őket, de a szerzőpáros csupán annyit mond ki az átmenettel kapcsolatban - Jegadeesh-Titman 
[1993] eredményeihez hasonlóan -, hogy történik megfordulás a két portfólió között. McLean [2010] pedig tanulmányában az egyedi kockázat (idiosyncratic risk) szempontjából közelíti meg a két jelenséget: melyik mennyiben vezethető vissza a részvények egyedi kockázatára, és nem tér ki a két jelenség közötti összefüggésre. Ezzel Simon [2002] sem foglalkozik, ő iparági (ingatlanpiaci vállalatok) szinten vizsgálja a lendületstratégiát, és hosszú távon szintén felleli a reverziós jelenséget.

Szintén együtt kezeli a lendület- és kontrariánus stratégia jövedelmezőségét $\mathrm{He}-\mathrm{Li}$ [2007], amely tanulmánynak legnagyobb hozzáadott értéke, hogy a szerzők folytonos heterogén szereplös ügynökalapú modellel (heterogeneous agent model, HAM) vizsgálják az általuk generált „kísérleti” hozamokat. Ezzel egy - a témában - korábban nem alkalmazott egységes elméleti keretet teremtett a különbözö anomáliákon alapuló kereskedési stratégiák profitabilitásának mérésére. Ebben a tekintetben a szerzőpáros arra az eredményre jut, hogy a lendületstratégia rövid távon jövedelmezően müködik, hosszú távon veszteséges, és éppen az ellenkezője figyelhető meg a kontrariánus stratégia esetén.

Az időtávokat illetően hasonló eredményt közöl Hong-Stein [1999] is a két stratégiával kapcsolatban, az elemzésük kiegészül az információk megjelenésének időpontjával és a részvények relatív elemzettségével. Eszerint a reverzió és a lendülethatás mértéke nagyban függ attól is, hogy adott részvényeket mennyire követik a mértékadó elemzőházak.

Ahogy már említettük, kevés olyan elemzés készült az eddigiekben, amely egy lokális piacon vizsgálta volna a tárgyalt anomáliákat: a spanyol tőzsdén teszteli a reverziót Alonso-Rubio [1990], a szerzőpáros szignifikánsnak találta a jelenséget - 24,5 százalékos eltérés az abnormális hozamban a vesztesek javára -, még akkor is, ha mérethatást kiszürték az eredményből. Antoniou és szerzőtársai [2005] pedig azt elemzi, hogy az athéni értéktőzsdén (Athens Stock Exchange, ASE) megfigyelhetö-e a reverziós jelenség. A szerzők - részben ellentétesen a korábbi irodalmakkal - rövid távú reverziót találnak, amely legerősebben ez esetben is a mérettől függ.

Végül megemlítjük Fama [1998] véleményét a piaci hatékonyságot megkérdőjelező eredményekről: szerinte ezen anomáliák csupán módszertani kérdéseken múlnak, és sokszor véletlen eredménynek tekinthetők. A hosszú távú piaci anomáliák pedig törékenyek, és csupán eseti jellegűek, de semmiképpen sem indokolják a piaci hatékonyság kétségbevonását.

A Budapesti Értéktőzsdével kapcsolatos elemzések jellemzően a piaci hatékonyság vizsgálatára irányulnak (lásd például Rappai [1995], Andor és szerzőtársai [1999] vagy Lukács [2003]), s nem a túlreagálási jelenséghez, amelyekröl jó áttekintést ad az eredményeket rendszerező Molnár [2006b]). A befektetői túlreagálással kapcsolatosan a Budapesti Értéktőzsde esetében Nagy-Ulbert [2007], valamint Marton [2001] végzett empirikus vizsgálatot. Marton [2001], bizonyos értelemben Jegadeesh-Titman [1993] módszeréhez hasonlóan, sorozatkorrelációs modellel azonosított hosszú távon túlreagálási jelenséget. Nagy-Ulbert [2007] ugyanakkor a lendület és a reverzió jelenségét két periódus (1999-2001 és 2005-2007) alapján, kilenc részvényre nézve vizsgálta, a tőkepiaci anomáliák rendszerezése mellett. A szerzők e tekintetben elfogadták De BondtThaler [1985] reverzióra vonatkozó eredményét, de - ahogy ki is emelték - túl rövid 
az általuk vizsgált időtáv ahhoz, hogy biztosan elfogadhassák a túlreagálási hipotézist, hosszabb idősorra lenne szükség az állítás bizonyítására.

Jelen tanulmány a Budapesti Értéktőzsde részvényeire vonatkozóan végez átfogó és részletes elemzést. Átfogó, mert a rendelkezésre álló lehető leghosszabb idősort használja fel a túlreagálási hipotézis tesztelésére, és az eredményeket statisztikai teszteknek veti alá. Részletes a vizsgálat abban az értelemben, hogy az elemzést különböző hosszúságú megfigyelési és tesztperiódusra is elvégzi. Erre vonatkozó tanulmányok tudomásunk szerint a magyar tőzsdére még nem jelentek meg.

\section{A befektetői túlreagálás vizsgálata a Budapesti Értéktőzsde részvényein keresztül}

A szakirodalmi ismertető után magyar adatokon - a Budapesti Értéktőzsde részvényein keresztül - vizsgáljuk a túlreagálási hipotézist. Ez nem jelent mást, mint hogy a megfigyelési periódusban túl- és alulteljesítő részvényeket megvizsgáljuk a következő periódusban, hogy lássuk, azok helyet cseréltek-e, vagy pedig sem.

\section{A felhasznált adatokról röviden}

A Budapesti Értéktőzsdén kereskedett részvények árfolyamát 1991-ig visszamenőleg a Bloomberg ügynökségen közölt által adatok alapján vizsgáltuk. A Bloomberg részvényárfolyamainak nagy előnye, hogy azokat a különböző hirtelen árfolyammozgást okozó eseményekkel korrigálják. Ennek megfelelően az elemzéshez használt árfolyamok nem tartalmazzák a részvényaprózás, részvényösszevonás, osztalékfizetés és egyéb tőkeváltozás okozta fellépő mozgásokat.

Csupán $A$ kategóriás részvényeket vizsgáltunk és néhány, forgalom alapján kiemelkedő $B$ kategóriás részvényt, ugyanis ez utóbbiak többségénél likviditási problémák merülnének fel az elemzés szempontjából. A piaci portfóliónak a BUX indexet tekintettük, míg kockázatmentes hozamnak az Államadósság Kezelő Központ Zrt. által kibocsátott 12 hónapos lejáratú diszkontkincstárjegy hozamát. Ez utóbbi idősort az Államadósság Kezelő Központ Adatszolgáltatási Osztálya bocsátotta rendelkezésünkre visszamenőleg egészen 1996 decemberéig, amikortól ezek az adatok megvannak. ${ }^{2}$ Így az elemzés az 1996. december és 2015. március közötti időszakot fogja át. ${ }^{3}$ A számítások Microsoft Excel, Microsoft Visual Basic és IHS Eviews programcsomagokkal történtek.

Tekintve a magyar tőkepiac méretét, választhattunk volna olyan tőzsdét is, ahol hosszabb és stabilabb adatsor áll rendelkezésünkre. Azonban a tanulmány

\footnotetext{
${ }^{2}$ Köszönettel tartozom az Államadósság Kezelő Központ Adatszolgáltatási Osztályának az adatokért, valamint a Budapesti Corvinus Egyetem Befektetési és Vállalati Pénzügyek Tanszékének, hogy hozzáférést biztosítottak az általuk üzemeltetett Bloomberg kereskedési teremhez.

${ }^{3}$ Nem a kockázatmentes hozam jelentette a szűk keresztmetszetet, hiszen 1997 előtt a BUX-on jelen lévő részvények száma tíz alatt volt, amivel érdemben nehéz lett volna dolgozni.
} 
elkészítésekor fontos szempont volt, hogy a korábbi elemzésekkel szemben egy kisebb és kevésbé likvid piacon is tesztelésre kerüljön a túlreagálási jelenség, ugyanis nem feltétlenül teljesül jelen esetben is a hipotézis, amely fakadhat az eltérö piacméretből, ahol a befektetők relatíve eltérő módon értékelhetnek adott információt.

Statisztikai szempontból előnyös lehetett volna Kelet-Közép-Európa piacain elemzést készíteni, amely kétségtelenül nagyobb elemszámú mintát biztosított volna, ugyanakkor az amerikai piachoz képest méret tekintetében még mindig eltörpül. Ezek a piacok azonban meglehetősen lokálisak és szeparáltak egymástól, kivéve egy-egy piac néhány vezető részvényét, így a nagyobb mintát leszámítva - amely bár fontos szempont - nem származott volna más előny a régiós tőzsdék együttes vizsgálatából.

Ugyanakkor Rouwenhorst [1997] számos problémát említ több ország piacának együttes vizsgálata esetén, amelyek torzíthatják az eredményt, ezáltal további elemzést igényelnek. Ezek közül legfontosabb a mérethatás (nagy cégek felül- vagy alulreprezentáltak az országok között), Kelet-Közép-Európában a tőzsdék eltérő „fejlettsége” (ezáltal a részvények kockázata), illetve az országok eltérő gazdasági teljesítménye a vizsgált időszakban. Utóbbi esetben például az eltérő gazdasági teljesítmény hatására a „nyertes” és „vesztes” részvények egy adott ország tőzsdéjén csoportosulhatnak, ha egyenlő súlyozású indexhez mérjük a teljesítményüket, ami pedig torzítja az eredményeket. Mindezen szempontokat figyelembe véve a budapesti tőzsde elemzését választottuk.

\section{Az alkalmazott módszertan és a túlreagálási hipotézis ellenörzésének lépései}

Mint azt említettük, a témában megjelent tanulmányok különféle módszertant alkalmaztak, noha az alapgondolat megegyező volt. Jellemzően a rövidebb idősorok esetében sorozatkorrelációs módszerrel vizsgálták a kapcsolatot a különböző időszaki hozamok között (lásd például Jegadeesh-Titman [1993]), míg több esetben - így De Bondt-Thaler [1985] is - az abnormális hozamok bizonyos szabályok szerinti összegzését végezték el, s ez alapján értékelték a túlreagálási hipotézist. Tekintve, hogy elsősorban hosszabb periódusokat vizsgálva hosszabb távú kapcsolatot kerestünk, az abnormális hozamok szerint végeztük számításainkat.

A modell felépítésének alapja a hatékony piacok elméletének a jövőbeli hozamra vonatkozó állítása, hiszen ezen a ponton érkezik a viselkedési pénzügyek egy fontos kritikája. A hatékony piacok elmélete szerint az árak minden rendelkezésre álló információt tartalmaznak, azaz a piac akkor hatékony, ha egy új információ azonnal beépül a piacon lévő összes árba. E szerint azonban várható értékben a realizált hozamnak meg kell egyeznie az elvárt hozammal, vagyis

$E\left(A R_{i, t} \mid F_{t-1}\right)=E\left(R_{i, t}-\tilde{R}_{t} \mid F_{t-1}\right)=0$,

ahol $A R_{i, t}$ jelöli az $i$-edik részvény abnormális hozamát a $t$-edik időpontban, amely a részvény adott időszaki hozama $\left(R_{i, t}\right)$ és az részvénytől elvárt hozam $\left(\tilde{R}_{t}\right)$ különbségeként adódik az $F_{t-1}$ időszakban elérhető információ alapján. Ebböl következően 
az abnormális hozamok várható értékének 0 -val való egyezősége, vagyis a reziduális hozamok nulla értéke az a pont, amely - piaci anomáliák lévén - a viselkedési pénzügyek több eredménye szerint a gyakorlatban nem teljesül.

A tanulmány egyik célja tehát az előző gondolatmenet megvizsgálása a Budapesti Értéktőzsde részvényein keresztül, egészen pontosan annak tesztelése, hogy a reziduális hozamok milyen struktúrát követnek a képzett alul- és túlteljesítő portfóliók esetében. Ennek értelmében elsőként feldaraboltuk a 1997 januárja és 2015 márciusa közötti havi hozamok idősorait - minden egyes részvényre vonatkozóan - hatéves periódusokra olyan módon, hogy a hatéves periódusok háromévente kezdődnek (1996. december-2002. december; 2000. január-2005. december; ...). Összecsúsztattuk tehát a periódusokat három évre, éppen annyira, hogy a függetlenség ne sérüljön. Eszerint a hatéves periódus (72 hónap) közepe lesz a $t=0$ időpont, ettől negatív irányban van a megfigyelési intervallum, pozitív irányban pedig a tesztperiódus. Vagyis az elsőt leszámítva minden megfigyelési periódus egyben tesztperiódus is, kivéve az utolsót, amely csak tesztperiódus. Így összesen $n=5$ tesztperiódusunk lett, amelyek függetlenek egymástól. A megfigyelési periódus alapján képeztünk alul- és túlteljesítő portfóliókat, a tesztperiódusban pedig a képzett portfóliók teljesítményét vizsgáltuk.

A portfóliók képzése az abnormális hozamok alapján történt, kérdés azonban, hogy mihez képest értelmezzük az abnormális hozamot. Lehet viszonyítási alap a piaci hozam, azaz egy adott részvényindex, jelen esetben a BUX index hozama. Ezzel szemben kiindulás lehet egy elvárt hozamot becslö elméleti modell is, így a tőkepiaci árfolyamok modellje (CAPM) vagy az arra épülő többtényezős modellek. Először bemutatjuk a CAPM alapján becsült abnormális hozamokat, majd az egyedi hozam és a piaci hozam különbségeként értelmezett abnormálishozam-számítással kapott eredményeket is. Fontos megjegyezni, hogy a CAPM klasszikus formájának használata azt az implicit feltevést feltételezi, hogy a befektetők megtakarításaikból csak a magyar piacon forgalmazott részvényeket vásárolnak - és a vagyonukat is itt költik el -, amiből következően a CAPM ezen formája torzíthat, hiszen minden befektetöre feltehetően nem igaz a kikötés.

Elsőként minden $j$-edik részvényre, minden $n$-edik megfigyelési periódus $t$-edik hónapjában - a megfigyelési perióduson belül - megbecsültük a CAPM alapján az elvárt hozamot $\left(\tilde{R}_{n_{j}, t}\right)$. Ez az

$\tilde{R}_{n_{j}, t}=R_{n, t}^{f}+\beta_{n_{j}}\left(R_{n, t}^{m}-R_{n, t}^{f}\right)$

egyenletből kapható meg, ahol $R_{n, t}^{f}$ a kockázatmentes hozam, az $R_{n, t}^{m}$ a piaci hozam (ez esetben a BUX index). A $\beta$ a szokásos módon adódik minden periódus $(n)$ minden részvényére $(j)$, azaz minden periódusban eltérő az egyes papírok $\beta$-ja, ami $n \times j$ számú $\beta$-t jelent összesen. Az így megkapott elvárt hozamot kivonva a realizált hozamból adódik az abnormális hozam $\left(A R_{n_{j}, t}\right)$. Képletben: $A R_{n_{j}, t}=R_{n_{j}, t}-\tilde{R}_{n_{j}, t}, \mathrm{~s}$ tulajdonképpen ezek az abnormális hozamok az alkotóelemei a modellnek. Ezt összegezve megkapható a pénzügyekben gyakran használt fogalom, a kumulált abnormális hozam (cumulated abnormal return, CAR): 
$C A R_{n_{j}}=\sum_{t=-35}^{0} A R_{n_{j},}$.

Ezek alapján minden periódusban könnyedén kiválaszthatók a túl- és alulteljesítő portfóliók. Alsó, illetve felső decilis alapján három körüli érék adódott, így minden periódusban három-három részvény került az alul-, illetve túlteljesítő portfólióba. Abban az esetben, ha egy adott részvény bekerült valamelyik portfólióba a megfigyelési periódus alapján, de megszünt a tesztperiódusban a tőzsdei kereskedése, úgy az adott portfólió újrasúlyozásra került a kivezetés pillanatában - összhangban $D e$ Bondt-Thaler [1985] megoldásával -, elkerülve ezáltal azt a túlélési torzítást, hogy a csődbe ment cégek, amelyek rontanák a portfólió teljesítményét, nem szerepelnek az elemzésben. Miután megkaptuk a két portfóliócsoport elemeit minden $n$-edik megfigyelési periódusra, minden megfigyelési periódust követő tesztperiódusban a $t$-edik $(t=1,2, \ldots, 36)$ időpontokra kiszámoltuk a két portfóliót alkotó részvények kumulált abnormális hozamait $\left(C A R_{n_{j}, t}\right) \cdot{ }^{4}$ Ezeket minden $n$-edik periódusban és $t$-edik idöpontban a részvények ( $j$-edik) szerint átlagoltuk a két csoportban, azaz

$A C A R_{n, t}=\frac{\sum_{j=1}^{k} C A R_{n_{j}, t}}{k}$,

majd ezt pedig $n$-re nézve is átlagoltuk a két csoportban, sígy megkaptuk a túl- és alulteljesítő portfóliók átlagos teljesítményét ( $t$-től függő görbéjét) a tesztperiódusban:

$A C A R_{t}=\frac{\sum_{n=1}^{5} A C A R_{n, t}}{5}$.

E mutatót kiszámolva mindkét csoportra és minden $t$-edik $(t=1,2, \ldots, 36)$ időpontra [ACAR ${ }_{t}^{A}$ és $A C A R_{t}^{T}$, mint alul- ( $A$ felső index) és túlteljesítő ( $T$ felső index) portfólió], látható lesz a múltban túl- és alulteljesítő részvényportfóliók kumulált abnormális hozama a következő három évben. Ha ezeket az értékeket is átlagoljuk a csoportokra nézve az idő ( $t$ ) szerint, akkor pedig eljutunk az $A C A R_{A t l}^{A}$ és $A C A R_{A t l}^{T}$ kifejezésekhez, amelyek egyetlen mutatóba sürítik az alul- és túlreagálás mértékét. E két kifejezésnek a hipotézisvizsgálatnál van jelentősége.

A túlreagálási hipotézis értelmében ugyanis azt kell tesztelni, hogy az alulteljesítő portfólió átlagos kumulált abnormális hozama meghaladja-e a túlteljesítő portfólió ugyanezen mutatóját. Ennek alapján a hipotézis formalizálva a következő lesz:

$$
\begin{aligned}
& H_{0}: A C A R_{\tilde{A} t l}^{A}-A C A R_{A t l}^{T}=0, \\
& H_{1}: A C A R_{A t l}^{A}-A C A R_{A t l}^{T}>0 .
\end{aligned}
$$

A $H_{0}$ hipotézis szerint a két portfólió átlagos kumulált abnormális hozama nem különbözik szignifikánsan egymástól, míg a $H_{1}$ szerint a vesztes (alulteljesítő) részvények szignifikánsan jobban teljesítenek a nyertes (túlteljesítő) részvényeknél.

\footnotetext{
${ }^{4}$ Például hároméves tesztperiódus esetén a 10. hónapban $C A R_{n_{j}}=\sum_{t=1}^{10} A R_{n_{j}, t}$, a 36. hónapban $C A R_{n_{j}}=\sum_{t=1}^{36} A R_{n_{j}, t}$.
} 
A hipotézisvizsgálatra elsőként a Student-féle $t$-próbát alkalmaztuk, jelen esetben ebben fontos kitétel az abnormális hozamok normális eloszlása. Amennyiben a normalitás nem teljesül, további nem paraméteres próbára is szükség van.

Annak ellenőrzésére, hogy mennyire fogadható el a normális eloszlás feltételezése, Jarque-Bera-próbát használtunk, amely az eloszlás csúcsossága (kurtosis) és ferdesége (skewness) alapján hoz döntést a normalitás létezéséről. A 2 szabadságfokú $\chi^{2}$ eloszlás 95 százalékos kvantilisértéke 5,99, így e kritikus értékhez képest döntöttünk a normalitás elfogadásáról. Az egyes részvények abnormális hozamai Jarque-Berapróbájának kritikus értékeit a Függelék F1. táblázata tartalmazza. A p-értékek hat részvény kivételével kisebbek, mint 5 százalék, azaz a hat részvényt leszámítva nem tekinthetők normális eloszlásúnak az abnormális hozamok.

$\mathrm{A} z$ eredmény értelmében a Student-féle $t$-próba mellett a nem paraméteres Wilcoxon-próbát (kétmintás) is alkalmaztuk, amely a két portfólió-idősor mediánjára fogalmazza meg a korábban az átlag egyezőségére tett hipotézist. Elviekben a próba alkalmazásának feltétele a folytonos eloszlás, azonban a gyakorlatban helytállónak tekinthető a próba diszkrét eloszlások esetén is, és számos helyen használják is (Hunyadi és szerzötársai [2001]).

\section{Eredmények}

Az alkalmazott modellnek és az elemzés lépéseinek, valamint a használt statisztikai próbáknak az ismertetése után értelmezzük a kapott eredményt. A 2. ábra mutatja a két portfóliócsoport teljesítményét a megfigyelési periódus végétől számítva 36 hónapig.

\section{2. ábra}

A túl- és alulteljesítő portfóliók a tesztperiódusban

CAR (kumulált abnormális hozam)

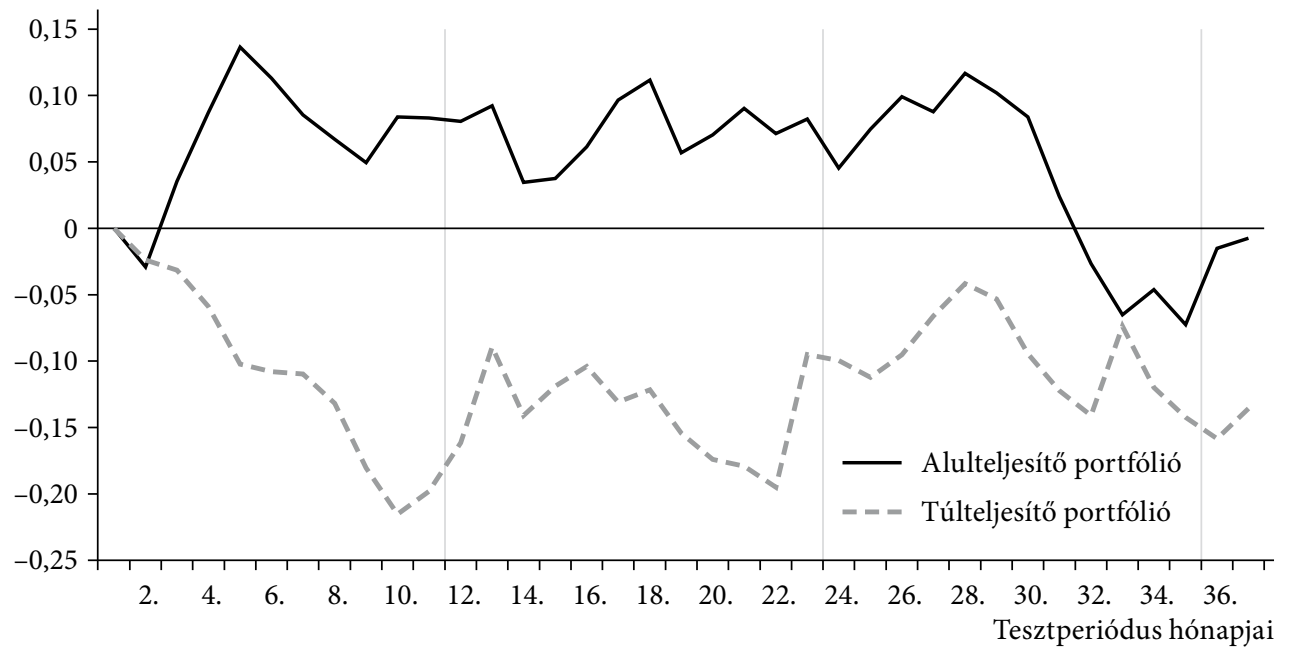

Forrás: saját számítás és szerkesztés. 
Ennek értelmében a következő következtetés vonható le: egyrészt azonnal megtörténik a reverziós jelenség, azaz a megfigyelési periódust követő első hónapokban az alulteljesítő portfóliók valóban a túlteljesítők fölött haladnak. Ez ellentmond azoknak a korábbi állításoknak, hogy a kezdetbeli pozitív korreláció után csak hosszabb távon lesz negatív a kapcsolat (Jegadeesh-Titman [1993], Rabin, [2002]), ugyanakkor összhangban van De Bondt-Thaler [1985] eredményével. Másrészt, ha De Bondt-Thaler [1985] eredményével (1. ábra) hasonlítjuk össze a kapott grafikont, jelentős eltérés, hogy jelen esetben a tesztperiódus végéhez közeledve csökken a két portfólió közötti különbség, azaz ha anomáliáról is van szó, az megszűnni látszik. Megfigyelhető továbbá, hogy a vesztes portfóliók a tesztperiódus vége felé már nem lesznek túlteljesítők: csupán az első 26-28. hónapban pozitív az abnormális hozam.

Jogosan merül fel a kérdés, hogy mennyire tekinthető az eredmény robusztusnak. Mielőtt statisztikai próbákkal támasztanánk alá az eredményeket, elsőként más módon teszünk kísérletet az eredmények robusztusságának növelésére. Az eddigiekben a CAPM által meghatározott elvárt hozamhoz képest definiáltuk az abnormális hozamot. Kifejtettük, hogy az abnormális hozam meghatározható az egyedi és a piaci hozamok különbségeként is, így elkészítettük az elemzést ez utóbbi módon, hiszen De Bondt-Thaler [1985] eredményének egyik jelentős kritikája volt, hogy csupán egy módszer alapján dolgoztak. Ezek alapján tehát az abnormális hozamot $A R_{n_{j}, t}=R_{n_{j}, t}-R_{n, t}^{m}$ módon definiáljuk, ahol $R_{n, t}^{m}$ a piaci hozam - jelen esetben ez a BUX index (3. ábra).

\section{3. ábra}

A túl- és alulteljesítő portfóliók a tesztperiódusban, $A R_{n_{j}, t}=R_{n_{j}, t}-R_{n, t}^{m}$ esetben, háromhárom éves megfigyelési és tesztperiódus esetén

CAR (kumulált abnormális hozam)

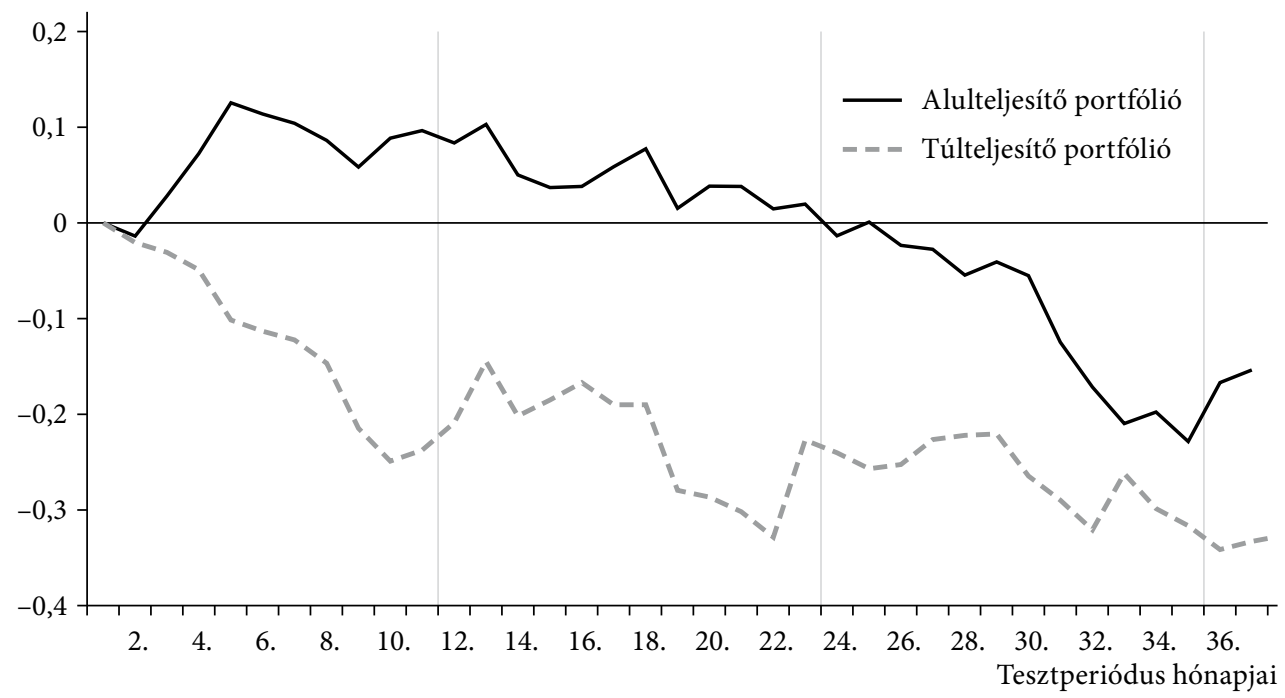

Forrás: saját számítás és szerkesztés. 
Az eredmény jól igazolja a korábbi, tőkepiaci árfolyamok modelljén (CAPM) alapuló abnormális hozammal kapott 2. ábrát. Ebben az esetben is azonnal bekövetkezik a reverzió, és a két portfólió közötti különbség jelentősnek mondható. A tesztperiódus végén észlelt közelítés a két portfólió tekintetében itt is fellelhető, azaz mindenképpen gyengülő reverzió tapasztalható. Az alulteljesítő portfólió kumulált abnormális hozama még inkább csökkenő és negatívba menő struktúrát követ, azaz nem válik túlteljesítővé. Statisztikailag tesztelve a $H_{0}: A C A R_{A t l}^{A}=0$ hipotézist Student-féle $t$-próbával, $-0,23$ érték adódik a tesztstatisztikára 0,81 $p$-értékkel. Ezek szerint az átlag negatív, de a piacot - azaz a BUX indexet - szignifikánsan nem teljesíti alul az alulteljesítő portfólió.

Az ábrák értelmezését követően elvégeztük a korábban említett próbákat annak érdekében, hogy statisztikailag is alátámasszuk a kapott eredményeket, növelve ezáltal az elemzés robusztusságát. Az 1. táblázat együttesen tartalmazza a két megközelítésre vonatkozóan az egyes statisztikai teszteket és a hozzájuk tartozó p-értékeket.

\section{1. táblázat}

$A H_{0}: A C A R_{A ̂ t l}^{A}-A C A R_{\tilde{A} t l}^{T}=0$ hipotézis Student-féle $t$-próbája, Wilcoxon-próbája (kétmintás), valamint a Kruskal-Wallis-tesztje a kétféle abnormális hozam megközelítésében

\begin{tabular}{lcclcc}
\hline \multirow{2}{*}{ Próba } & \multicolumn{2}{c}{ CAPM } & & \multicolumn{2}{c}{ Piaci hozam } \\
\cline { 2 - 3 } \cline { 5 - 6 } & tesztstatisztika & $p$ & & tesztstatisztika & $p$ \\
\hline Student-féle $t$ & 14,08 & 0,0000 & & 9,46 & 0,0000 \\
Wilcoxon & 7,14 & 0,0000 & & 6,30 & 0,0000 \\
Kruskal-Wallis & 51,06 & 0,0000 & & 39,72 & 0,0000 \\
\hline
\end{tabular}

Forrás: saját számítás és szerkesztés.

A korábban levont következtetést a tesztek is megerösítették, hiszen a p-értékek kellöen kicsik, azaz valamennyi teszt értelmében szignifikáns különbség mutatkozott abban a tekintetben, hogy a vesztes portfólió „megveri” a „nyertes” portfóliót mind a CAPM, mind pedig a BUX index alapján vizsgálva az abnormális hozamot. Érdemes még kiemelni szintén az 1. táblázatban szereplö Kruskal-Wallis-próbát, amely a Wilcoxon-próba kiterjesztése kettőnél több mintára, de gyakorlatilag az elv megegyezik, így a két próba jellemzően hasonló eredményt ad.

Mindkét megközelítés esetében - de különösen a piaci alapú abnormális hozamoknál - meg lehetett figyelni az alulteljesítő portfólió relatíve gyenge teljesítményét, elsősorban a tesztperiódus második felében. Érdemes ez alapján a válság éveinek kiszűrésével megnézni az eredményt, ugyanis előfordulhat, hogy a válság időszaka - mint a hozamokra nagyban ható esemény - jelentősen módosítja a két portfólió kumulált abnormális hozamának idősorát. A vizsgálatot a piaci alapú megközelítés esetében végeztük el, ugyanis ott volt szembetünőbb a jelenség (4. ábra).

A 4. ábrát összehasonlítva a korábbiakkal, a reverzió azonnali bekövetkezése, illetve a hozamkülönbség - ezáltal az anomália - csökkenése vagy megszünése itt is megfigyelhetö. A portfóliók abszolút teljesítményére vonatkozóan viszont változik az eredmény. 


\section{4. ábra}

A túl- és alulteljesítő portfóliók a tesztperiódusban, $A R_{n_{j}, t}=R_{n_{j}, t}-R_{n, t}^{m}$ esetben, három-három éves megfigyelési és tesztperiódus esetén, a válság éveinek kihagyásával

CAR (kumulált abnormális hozam)

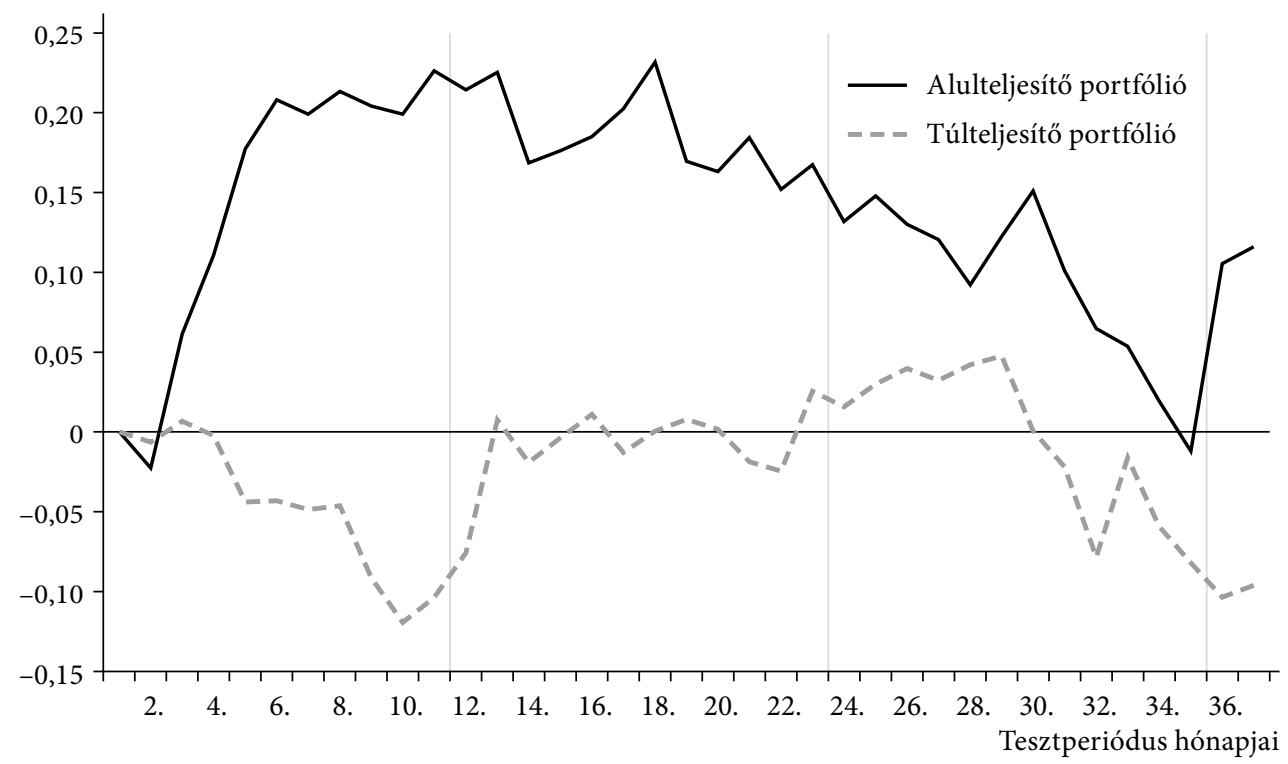

Forrás: saját számítás és szerkesztés.

A korábban alulteljesítő portfólió most pozitív abnormális hozamot ér el a tesztperiódusban, noha a trend itt is csökkenő a kezdeti emelkedés után, vagyis hosszú távon nem teljesíti túl a piacot, szemben De Bondt-Thaler [1985] eredményével.

Az eddigiekben elemzett ábrák és az elvégzett tesztek alapján összefoglalóan a következő állítások tehetők a túlreagálási hipotézissel kapcsolatban.

1. EREDMÉNY - A bemutatott két abnormálishozam-megközelítés alapján számolt, hároméves megfigyelési periódusok alapján számított tesztperiódus esetében

- elfogadható a befektetői túlreagálás, teljesül a reverziós jelenség, azaz a vesztes portfóliók „megverik” a „nyertes” portfóliókat a tesztperiódusban;

- a kapott anomália nem marad fenn hosszú távon, a tesztperiódus vége felé egyre inkább gyengül, megszűnik;

- a vesztes portfóliók a válság kiszűrésével képesek csak pozitív hozamokat elérni, addig ugyanis a tölcsér ellenére nulla körüli marad az átlagos abnormális hozam, tehát nem teljesítik túl a piacot.

A kapott eredményeket mindenképpen érdemes összevetni a témában megjelent korábbi eredményekkel. Ennek megfelelően a reverziós jelenség tekintetében elfogadható De Bondt-Thaler [1985] eredménye, amely szerint a reverzió bekövetkezik a tesztperiódus elején. Ezzel együtt a hároméves megfigyelési és tesztperiódusokkal elkészített 
elemzés cáfolja Jegadeesh-Titman [1993] által talált lendülethatást, valamint NagyUlbert [2007] eredményét, ez utóbbi szerzőpáros két periódus vizsgálata alapján arra jutott, hogy a reverzió nem azonnal következik be. Mindezek mellett hangsúlyozni kell azt is, hogy a talált reverzió a tesztperiódus második felében egyre inkább gyengül, majd megszünik, ami ellentétben áll De Bondt-Thaler [1985] eredményével.

Ebben a részben a befektetői túlreagálási hipotézist vizsgáltuk a Budapesti Értéktőzsde részvényein keresztül, s igazolást nyert a túlreagálási jelenség teljesülése, azonban az egyes vonások némiképpen árnyalják az összhangot, és részben ellentmondásban állnak a korábbi állításokkal.

\section{A portfóliók teljesítménye és a megfigyelési periódus közötti kapcsolat}

A továbbiakban arra a kérdésre keressük a választ, hogy mennyiben függ a reverzió bekövetkezése a megfigyelési és kiértékelési időszak hosszától. Ennek a vizsgálatnak az az elsődleges oka, hogy az irodalmak egyik része a reverzió mellett érvel, másik része a lendülethatás mellett. Abban összhangban vannak az eredmények, hogy egy bizonyos idő elteltével történik megfordulás a két portfólió tekintetében, de azt nem tudjuk, hogy ez a megfordulás mikor történik meg. Azt sem elemezték mindeddig, hogy a megfigyelési időtáv hogyan befolyásolja ezt a megfordulást, más szavakkal: független-e a „nyertes” és a „vesztes” portfólió reverziójának bekövetkezése a megfigyelési időtávtól? Az eddigi elemzés során a két portfólió mindkét megközelítés esetében azonnal helyet cserélt, azaz bekövetkezett a reverzió, ugyanakkor valamennyi számítás három-három éves megfigyelési és tesztperiódus alapján történt. Kérdés tehát, hogy más intervallum választása esetén mit mondhatunk a reverzió és lendülethatás kapcsolatáról.

Az elemzés módszertana megegyezik a korábbiakban alkalmazottal, azonban ha a teljesítmény és a megfigyelési periódus függetlenségének vizsgálata a cél, akkor több, különböző hosszúságú megfigyelési periódust kell képezni. Ennek értelmében a megfigyelési periódust 3, 6, 9, 12, 18, 24, 30, 36 hónaposnak választottuk meg, így a különböző hoszszúságú periódusok esetén látható a két portfólió tesztperiódusbeli mozgása.

Korábban részletesen tárgyaltuk az elemzés menetét a hároméves (36 hónapos) esetre, amelyben mind a megfigyelési, mind pedig a tesztperiódus hossza 36 hónap volt. Jelen esetben a 3, 6, 9, 12 hónapos megfigyelési periódusnál kétszeres hosszúságúnak választottuk a tesztperiódust, hogy látszódjon az esetleges átmenet, azaz „legyen idö” a feltételezett reverzióra. Itt szintén ügyeltünk a függetlenség betartására, azaz a tesztperiódusok nem fedték egymást. Az egy évnél hosszabb megfigyelési periódusok esetében pedig konzisztensen a 24 hónapos tesztperiódusnál maradtunk a könnyebb összevethetőség érdekében. A korábbi számításoknál elöször a CAPM által becsült hozamhoz viszonyítva definiáltuk az abnormális hozamot, majd elvégeztük a számításokat a piaci hozam alapján számítva $\left(A R_{n_{i}, t}=R_{n_{i}, t}-R_{n, t}^{m}\right)$ is. Most is bemutatjuk mindkét megközelítés eredményét. Ha ugyanis az abnormális hozam piacihozam-alapú megközelítése jut csak szignifikáns eredményre - míg a CAPM alapú nem jelez szignifikáns eltérést, amely a $\beta$-kat felhasználva ad becslést az elvárt hozamra -, akkor leginkább a két portfólió eltérő kockázata áll a háttérben, s nem a túlreagálás. 
Az eredményt grafikusan a Függelék F1. ábrája mutatja, amelyet helyhiány miatt csak a CAPM esetben közlünk, de hasonló eredményt adott a másik megközelítés is. Az ábrák alapján elmondható, hogy a 12 hónapnál rövidebb megfigyelési periódushossz esetén nem történt semmilyen értelemben reverzió, azaz fennmaradt a lendület, igazolva ezzel Jegadeesh-Titman [1993], valamint Rabin [2002] állítását. A 12 hónapos esetben szintén igaz a fenti állítás, ugyanakkor a két portfólió közötti különbség nem mondható jelentősnek, azaz nincs egyértelmű jele az anomáliák létezésének. Ami az egy éven túli megfigyelési periódusokat illeti, kivétel nélkül bekövetkezett a reverzió, azaz az alulteljesítő portfólió „megverte” a túlteljesítő portfóliót, összhangban $D e$ Bondt-Thaler [1985] eredményével. Ebből a csoportból a 24 hónapos eset kiemelendö, ahol az ábra alapján nem egyértelmű a reverzió.

Ezen eredmény alapján elmondható, hogy a reverzió és a lendülethatás közötti átmenet leginkább attól függ, hogy milyen hosszúnak választjuk meg a periódusokat, s nem pedig attól, hogy a tesztperiódus melyik szakaszában vagyunk, ahogyan állítja Rabin [2002]. Van azonban néhány eset az ábrák alapján, amikor nem azonnali a reverzió bekövetkezése, hanem az első 4-6 hónapban kitart a lendület, és csak ezután figyelhető meg a váltás. Ilyen a 12, 18, 30 hónapos intervallumválasztás, ami viszont igazolja a tesztperiódus során bekövetkező váltást, így további elemzést igényel, hogy a periódus hossza mellett befolyásolja-e a reverzió és lendület bekövetkezését a tesztperiódus adott szakasza. Meg kell még jegyeznünk, hogy a legtöbb ábrán fellelhető az a korábbi megállapítás, hogy míg a nyertes portfóliók rendszerint határozott vesztesekké válnak éven túli megfigyelési periódus esetén, addig a vesztesek leginkább nulla körül ingadoznak.

A két megközelítés eredményére jelen esetben is elvégeztük a Student-féle $t$-próbát és a Wilcoxon-próbát is annak érdekében, hogy statisztikailag is megalapozzuk a fenti állításokat (2. táblázat).

\section{2. táblázat}

A $H_{0}: A C A R_{A t l}^{A}-A C A R_{A t l}^{T}=0$ hipotézis Student-féle $t$ - és Wilcoxon-próbája az egyes megfigyelési periódusok szerint számított, kétféle kumulált abnormális hozam alapján

\begin{tabular}{|c|c|c|c|c|c|c|c|c|}
\hline \multirow{3}{*}{$\begin{array}{l}\text { Megfigyelési } \\
\text { periódusok } \\
\text { hossza (hónap) }\end{array}$} & \multicolumn{4}{|c|}{ CAPM } & \multicolumn{4}{|c|}{ Piaci hozam } \\
\hline & \multicolumn{2}{|c|}{ Wilcoxon } & \multicolumn{2}{|c|}{ Student-féle $t$} & \multicolumn{2}{|c|}{ Wilcoxon } & \multicolumn{2}{|c|}{ Student-féle $t$} \\
\hline & $U$ & p-érték & $t$ & p-érték & $U$ & p-érték & $t$ & p-érték \\
\hline 3 & 3,00 & 0,0027 & 5,48 & 0,0001 & 2,36 & 0,0181 & $-3,61$ & 0,0036 \\
\hline 6 & 3,92 & 0,0001 & $-5,87$ & 0,0000 & 3,82 & 0,0001 & $-5,01$ & 0,0000 \\
\hline 9 & 3,58 & 0,0003 & $-3,94$ & 0,0004 & 1,47 & 0,1404 & $-1,35$ & 0,1858 \\
\hline 12 & 2,96 & 0,0031 & $-3,38$ & 0,0015 & 1,33 & 0,1838 & $-1,25$ & 0,2186 \\
\hline 18 & 5,02 & 0,0000 & 7,13 & 0,0000 & 3,89 & 0,0001 & 5,44 & 0,0000 \\
\hline 24 & 4,06 & 0,0000 & 5,34 & 0,0000 & 4,67 & 0,0000 & 6,52 & 0,0000 \\
\hline 30 & 4,24 & 0,0000 & 5,58 & 0,0000 & 3,93 & 0,0001 & 4,38 & 0,0001 \\
\hline 36 & 6,01 & 0,0000 & 14,53 & 0,0000 & 6,01 & 0,0000 & 11,76 & 0,0000 \\
\hline
\end{tabular}

Forrás: saját számítás és szerkesztés. 
A 2. táblázat az egyes hosszúságú megfigyelési periódusokra számított tesztstatisztikákat és a hozzájuk tartozó p-értékeket mutatja mindkét megközelítésben. Elsőként érdemes a két megközelítés, majd a két teszt szerinti eredményeket összehasonlítani egymással. Ami a két eltérő módszert illeti, a tesztek két esetet kivéve azonos eredményt adnak: csak a 9 és a 12 hónapos esetben térnek el egymástól (ezekben a piacihozam-alapú megközelítés elfogadja a $H_{0}$ hipotézist, a másik nem). Mindkét próba a $H_{0}: A C A R_{A t l}^{A}-A C A R_{A t l}^{T}=0$ hipotézist teszteli, a Wilcoxon-próbára a nem normalitás teszteléséhez volt szükség. Látható, hogy mindkét próba ugyanazt az eredményt szolgáltatta minden egyes esetben, így elegendő az egyiket vizsgálni, hiszen a Wilcoxon-próba elsősorban a Student-féle t-próba megerösítésére szolgált. Ahogyan az F1. ábra alapján látszott, a 3 és a 6 hónapos periódusok esetében a tesztek minden esetben szignifikánsak 5 százalékos szinten, de negatív értékeket vesznek fel (Student-féle $t$-próba), míg a 9 és 12 hónapos periódusoknál látható némi megingás a piacihozam-alapú megközelítés esetében, azaz itt nem található szignifikáns módon létező anomália. Ezzel szemben a hosszabb periódusok esetében minden lehetséges szignifikanciaszinten elvetjük a $H_{0}$ hipotézist, azaz a vesztes portfólió jobban teljesít a nyertesnél. Összességében az eredmények jól alátámasztják a korábbiakat.

2. EREDMÉNY • A nyolc különbözö hosszúságú periódus alapján számított tesztperiódusbeli kumulált abnormális hozamok esetében

- a legtöbb esetben valamilyen irányú szisztematikus kapcsolat fennáll a két portfólió között, azaz nem teljesül a piaci hatékonyság a Budapesti Értéktőzsdén;

- az éven túli esetekben elfogadható a reverzió, azaz a vesztes portfóliók „megverik" a nyertes portfóliókat a tesztperiódusban. Ez az eredmény robusztus mind a CAPM-alapú, mind pedig a piacihozam-alapú abnormális hozam esetében;

- az évnél rövidebb megfigyelési intervallumok esetében - ellentétben $D e$ Bondt-Thaler [1985] eredményével - megmarad a lendület, azaz a túl(alul)teljesítö továbbra is túl(alul)teljesítő marad, igazolva ezzel a Jegadeesh-Titman [1993] által talált lendülethatást;

- a vesztes portfóliók csak nulla körüli vagy negatív kumulált abnormális hozamot képesek elérni, tehát nem teljesítik túl a piacot.

Az eredmények alapján elmondható, hogy éven belül nincs reverziós jelenség, egy év fölött pedig függetlenül a periódus hosszától, az alulteljesítő „megveri” a túlteljesítő portfóliót, vagyis az egyes anomáliák bekövetkezése leginkább a megfigyelési és tesztperiódus hosszától függ.

Az eredmények értelmezésénél felmerült, hogy némely éven túli esetben megfigyelhető a lendület az első hónapokban, így a kérdés mélyebb vizsgálata szükséges ahhoz, hogy az előbbi eredmények mellett az is kimondható legyen, hogy a tesztperiódus szakasza is befolyásolja az anomáliák bekövetkezését. Ennek megfelelöen minden periódus esetén „levágtuk” a tesztperiódust hat hónapnál, és csak az első hat értéket vizsgáltuk. Ez esetben a tesztek alapján elfogadható-e a reverziós jelenség a hosszabb periódusokra, vagy pedig ebben az esetben kitart a portfóliók lendülete a statisztikai tesztek alapján? Látszott ugyanis, hogy egyes periódusoknál nem egyértelmü az 
azonnali reverzió. ${ }^{5}$ Elvégeztük a teszteket a tesztperiódusok első hat hónapjaira, mind a CAPM, mind pedig a piaci hozamhoz mért abnormális hozam esetén (3. táblázat).

\section{3. táblázat}

A $H_{0}: A C A R_{A t l}^{A}-A C A R_{A t l}^{T}=0$ hipotézis tesztje az egyes megfigyelési periódusok szerint számított kumulált abnormális hozamok alapján a két megközelítést alkalmazva, a tesztperiódusok első hat hónapjára vonatkozóan

\begin{tabular}{|c|c|c|c|c|c|c|c|c|}
\hline \multirow{3}{*}{$\begin{array}{l}\text { Megfigyelési } \\
\text { periódusok } \\
\text { hossza (hónap) }\end{array}$} & \multicolumn{4}{|c|}{ CAPM } & \multicolumn{4}{|c|}{ Piaci hozam } \\
\hline & \multicolumn{2}{|c|}{ Wilcoxon } & \multicolumn{2}{|c|}{ Student-féle $t$} & \multicolumn{2}{|c|}{ Wilcoxon } & \multicolumn{2}{|c|}{ Student-féle $t$} \\
\hline & $U$ & p-érték & $t$ & p-érték & $U$ & $p$-érték & $t$ & $p$-érték \\
\hline 3 & 3,00 & 0,0027 & 5,48 & 0,0001 & 2,36 & 0,0181 & $-3,61$ & 0,0036 \\
\hline 6 & 2,87 & 0,0040 & $-5,80$ & 0,0001 & 2,75 & 0,0060 & $-5,22$ & 0,0002 \\
\hline 9 & 3,00 & 0,0027 & $-6,20$ & 0,0000 & 2,75 & 0,0060 & $-4,27$ & 0,0011 \\
\hline 12 & 0,45 & 0,6547 & $-0,98$ & 0,3444 & 0,32 & 0,7494 & 0,19 & 0,8507 \\
\hline 18 & 1,85 & 0,0639 & 2,54 & 0,0259 & 0,70 & 0,4822 & 1,85 & 0,0890 \\
\hline 24 & 0,96 & 0,3379 & 1,87 & 0,0862 & 2,49 & 0,0127 & 2,98 & 0,0116 \\
\hline 30 & 1,85 & 0,0639 & 2,22 & 0,0463 & 1,72 & 0,0845 & 2,16 & 0,0519 \\
\hline 36 & 2,75 & 0,0060 & 4,30 & 0,0010 & 2,87 & 0,0040 & 4,36 & 0,0009 \\
\hline
\end{tabular}

Forrás: saját számítás és szerkesztés.

Ebben az esetben is látható, hogy a két teszt konzisztens, azaz nem mond ellent egymásnak, így most is a Student-féle $t$-próbát vizsgáljuk mindkét megközelítés esetében. A tesztstatisztika értékei negatívak és szignifikánsak a három, hat és kilenc hónapos esetben mindkét módszer esetében. Az egy év, illetve annál hosszabb periódusoknál 5 százalékos szignifikanciaszinten eltérő eredményeket kaptunk a két megközelítés esetében, azonban összefoglalóan azt mondhatjuk, hogy ahol szignifikáns a két portfólió közötti eltérés, ott kivétel nélkül pozitív a Student-féle t-próba értéke. Azaz egy év fölött bizonyos esetekben már az első hat hónapban megtörténik a reverzió, míg a többi esetben az első hat hónapban nincs különbség a két portfólió abnormális hozama között. Ugyanakkor statisztikailag a lendülethatást nem figyelhetjük meg a hosszabb periódusok elején, az csak az éven belüli periódusok esetében igazolható. E megfontolások alapján tehát a következőket állíthatjuk.

3. EREDMÉNY • A tesztperiódusok első hat hónapjára vonatkozó tesztek alapján megállapítható, hogy

- éven belüli periódusok esetében a lendülethatás érvényesül, összhangban a korábbi eredményekkel;

- éven túli periódusok esetében vagy azonnal bekövetkezik a reverzió, vagy pedig nincs statisztikailag eltérés a két portfólió abnormális hozama között.

\footnotetext{
${ }^{5}$ Választhattuk volna az első 9 vagy 12 hónapot is, azonban az ábrák alapján az első 4-6 hónapban látható némi bizonytalanság. Másik megoldás az lett volna, ha minden időpontot külön vizsgálunk.
} 
Összességében azt mondhatjuk, az éven túli periódusok esetében nem tapasztalható a lendülethatás, vagyis a reverzió és a lendület közötti kapcsolat leginkább a megfigyelési periódus hosszának megválasztásától függ, rövid periódus esetén kitart a lendület, másfél év fölött pedig azonnal bekövetkezik a reverzió.

További kérdésként fogalmazható meg, hogy a két módszer alapján is helytálló eredmény - kiszürve így a két portfólió eltérő kockázatának hatását - mennyiben tulajdonítható esetlegesen a mérethatásnak (Chopra és szerzőtársai [1992], Zarovin [1989]), és nem a túlreagálási jelenségnek. Zarovin [1989] a mérethatást a két portfólió évenkénti átlagos piaci kapitalizációjának összevetésével vizsgálta, vagyis elemzésében az alkalmazott Student-féle $t$-próba $H_{0}$ hipotézise az átlag egyezőségére vonatkozott. Követve ezt a módszertant, kiszámoltuk minden intervallumfelosztásra az egyes csoportok portfólióinak átlagos piaci kapitalizációját, amelyek egyezőségét Studentféle $t$-próbával végeztük el. Fontos hangsúlyozni, hogy a piaci kapitalizáció megközelítően lognormális eloszlást követ, így a Student-féle $t$-próbát logaritmus transzformációval végeztük el (Zarovin [1989]).

A 4. táblázatból alapján látható, hogy a nyertes piaci portfólió átlagos kapitalizációja valamennyi esetben nagyobb, mint a vesztes portfólióé. Fontos kiemelni ugyanakkor, hogy a $p$-értékek alapján 5 százalékos szignifikanciaszinten négy esetben vetjük el a $H_{0}$ hipotézist, azaz az átlagos kapitalizáció egyezőségét, négy esetben pedig elfogadjuk azt (1 százalékos szignifikanciaszint esetén pedig egy esetben vetnénk el az egyezőséget). Azokban az esetekben tehát, amelyeknél szignifikáns a méretkülönbség, mindenképpen óvatosan kell kimondani a túlreagálási hipotézisről hozott eredményt, hiszen a mérethatás is állhat a háttérben, azaz a kis kapitalizációjú cégek „felülteljesítik” a nagyokat, és nem anomália okozza a két portfólió abnormális hozamának szisztematikus eltérését. Ugyanakkor a 9 és 12 hónapos esetben a korábbi eredmények (2. táblázat) sem hoznak egyöntetü döntést

\section{4. táblázat}

A nyertes és vesztes portfólió átlagos piaci kapitalizációja, a két átlag logaritmusának egyezőségére vonatkozó Student-féle $t$-próba eredménye és az ahhoz tartozó $p$-értékek

\begin{tabular}{|c|c|c|c|c|}
\hline \multirow{2}{*}{$\begin{array}{l}\text { Megfigyelési periódus } \\
\text { hossza (hónap) }\end{array}$} & Nyertes & Vesztes & \multicolumn{2}{|c|}{ Student-féle $t$-próba } \\
\hline & \multicolumn{2}{|c|}{ portfólió (millió forint) } & $t$ & p-érték \\
\hline 3 & 297572,3 & 238402,6 & 1,47 & 0,0718 \\
\hline 6 & 257920,8 & 178476,6 & 0,39 & 0,3474 \\
\hline 9 & 314577,2 & 221044,7 & 1,74 & 0,0458 \\
\hline 12 & 436322,9 & 73189,9 & 3,16 & 0,0022 \\
\hline 18 & 374607,4 & 139481,7 & 1,23 & 0,1188 \\
\hline 24 & 556481,5 & 62756,4 & 2,12 & 0,0301 \\
\hline 30 & 464852,1 & 83438,1 & 2,19 & 0,0300 \\
\hline 36 & 668077,6 & 247525,4 & 0,46 & 0,3304 \\
\hline
\end{tabular}

Forrás: saját számítás és szerkesztés. 
a túlreagálási hipotézis mellett, így a mérethatásnak a 24 és a 30 hónapos esetben lehet szerepe, a többi esetben vagy a reverziós jelenség, vagy pedig a lendülethatás teljesül a vizsgált portfóliók esetében.

Bizonyos mértékben ez az eredmény árnyalja ugyan a képet, így ha nem is valamennyi periódus esetében, de több esetben található anomália a Budapesti Értéktőzsdén, rövid periódusok esetén jellemzően a lendülethatás érvényesül, a hosszú periódusok esetében pedig a reverzió, amely fokozatosan gyengül, majd megszünik a vizsgált periódusok vége felé haladva.

\section{Összefoglalás}

Miután több módon is megvizsgáltuk a Budapesti Értéktőzsdét a piaci túlreagálási jelenséggel kapcsolatban, azaz összefüggést kerestünk a múltban a piacot túlés alulteljesítő portfóliók jövőbeli hozamai között, kérdés, hogy összességében mit mondhatunk az eredményekröl. Egybevág-e ez az eredmény a korábban megjelent tanulmányokéval, így például Jegadeesh-Titman [1993] által talált lendülethatást vagy De Bondt-Thaler [1985] eredményében definiált reverziót fogadhatjuk-e el, illetve kérdés, mennyire bizonyul szignifikánsnak ez az eredmény. Mivel e sokat említett tanulmányokat is erősen kritizálta a közgazdász-társadalom - hogy azok törékenyek és általánosan nem helytállók -, különösképpen a piaci hatékonyság elkötelezett hívei (így például Fama [1998]), így nyilván nem is volt cél egy mindennel szemben robusztus eredmény felállítása.

Összességében elfogadható a viselkedési pénzügyek azon állítása, hogy létezik túlreagálás a Budapesti Értéktőzsdén, és hogy a piaci hatékonyság számos esetben nem teljesül. Hosszú távon a korábban alulteljesítő portfólió valóban „,megveri” a túlteljesítő portfóliót, azaz teljesül a reverziós jelenség. Fontos eredmény azonban, hogy a talált anomália a periódus végéhez közeledve megszünik, azaz eltünik a két portfólió abnormális hozama közötti különbség. Kiszürve a válságot, tisztább struktúrát és magasabb hozamot produkáltak a portfóliók. Ezen túlmenően egyik alkalommal a CAPM alapján becsültük az abnormális hozamot, míg másik esetben az egyedi és piaci hozam eltéréseként definiáltuk azt, azonban az eredmény így is helytálló maradt, s statisztikailag is elfogadható lett.

Ezek után nyolc különböző hosszúságú megfigyelési periódus alapján is elvégeztük és statisztikailag teszteltük a számításokat: azt, hogy az alulteljesítő portfólió „megverte” a túlteljesítő portfóliót, érvényes maradt a hosszú, legalább másfél éves periódusokra, már az első teszthónapoktól. Ami azonban szintén igazolódott, hogy a rövid periódusok esetében kitart a lendület, azaz elmarad a reverzió. Ez alapján tehát elmondható, hogy a reverzió és a lendület közötti kapcsolat legnagyobb mértékben a periódusok hosszától függ, s kevésbé attól, hogy a tesztperiódus melyik szakaszában vagyunk. Ezek alapján viszont érthető, hogy $D e$ Bondt-Thaler [1985] nem észlelt hasonló változást, csupán annyit, hogy a különbség a későbbiekben válik szignifikánssá, hiszen a szerzők három- és ötéves intervallumokat képeztek. 
Az elemzés elkészítése még az említett korlátok ellenére is hasznosnak bizonyult, hiszen egy széles körü és statisztikailag is megalapozott vizsgálat a Budapesti Értéktőzsdén hozzájárulhat a magyar tőkepiac mélyebb elméleti megismeréséhez.

A jövőben egyrészt hosszabb tesztperiódus esetén (60-70 hónap) mélyebb vizsgálat alá lehetne vonni a két portfólió idősorát, hogy esetlegesen további összefüggéseket lehessen beazonosítani, így többek között a már említett januárhatást is, amelyre $D e$ Bondt-Thaler [1985] is kitért. Jelen esetben csak az autokovariancia lett volna használható a jelenség tesztelésére, amely már kevésbé mutatja az 12 hónapos ciklusokat, a spektrális sürüségfüggvény szempontjából pedig hosszabb idősorra lenne szükség, ami jól mutatná a kiemelkedő frekvenciákat, így a januárhatást.

Másrészt azonban a magyar adatok rövid és keresztmetszetben is kis mérete, valamint a részvények esetleges illikviditása miatt sokkal részletesebb elemzést nem feltétlen érdemes végezni a magyar piacon ezzel az elemzési kerettel, de hasznos volna a vizsgálatot kiterjeszteni a Kelet-Közép-Európai régióra is - figyelve az említett problémákra -, amely még mindig egy meglehetősen lokális piac, ugyanakkor a részvények számában és piaci kapitalizációban meghaladja a magyar tőzsdét. Szintén megfontolandó a kutatási kérdés bizonyos mértékű módosítása egy kisebb méretü piacon. Például ilyen feladat lehet az abnormális hozamok, áttételesen a túlreagálás okainak (esetleg az egyének korlátozott figyelme) keresése. ${ }^{6}$

Harmadrészt pedig érdemes lenne tesztelni, hogy a tanulmányban alkalmazott metódus gyakorlati értelemben is müködőképes modell-e, azaz figyelembe véve az egyes tranzakciós költségeket (vételi és eladási jutalékok, árfolyamnyereség-adó), mennyire tekinthető profitábilis kereskedési stratégiának az e módszer szerinti befektetés, kereskedés.

\section{Hivatkozások}

Alonso, A.-Rubio, G. [1990]: Overreaction in the Spanish Equity Market. Journal of Banking and Finance, Vol. 14. No. 2-3. 469-481. o. http://dx.doi.org/10.1016/0378-4266(90)90060-f. Andor György-Ormos Mihály-Szabó Balázs [1999]: Return Predictability in the Hungarian Capital Market. Periodica Politechnica, Vol. 7. No. 1. 29-45. o.

Antoniou, A.-Galariotis, E. C.-Spyrou, S. I. [2005]: Contrarian Profits and the Overreaction Hypothesis: the Case of the Athens Stock Exchange. European Financial Management, Vol.11. No. 1. 71-98. o. 10.1111/j.1354-7798.2005.00276.x.

Bachelier, L. [1900]: Théorie de la spéculation. Annales Scientifiques de l'École Normale Supérieure, Vol. 3. No. 17.21-86. o.

BALl, R.-Kothari, S. P. [1989]: Nonstationary Expected Returns: Implications for Tests of Market Efficiency and Serial Correlation in Returns. Journal of Financial Economics, Vol. 25. No. 1. 51-74. o. http://dx.doi.org/10.1016/0304-405x(89)90096-2.

\footnotetext{
${ }^{6}$ Az egyének korlátozott figyelmét - mely ugyancsak egy fontos témája a viselkedési pénzügyek tudományának - jól szemlélteti például Huberman-Tomer [2001] egy rákgyógyszert gyártó cég példáján, amelynek nem a nagy jelentőségű készítmény megszületése után ugrott meg permanens módon a részvényárfolyama a tőzsdén, hanem a mértékadó újság címlapján leközölt cikk után. Benartzi [2001] azt találja, hogy egy adott cég dolgozója attól függően vásárol a cég saját részvényéből, hogy az miként teljesített a közelmúltban, s nem pedig a cég pénzügyi mutatói alapján hozza meg döntését.
} 
Barberis, N.-Shleifer, A.-Vishny, R. [1998]: A Model of Investor Sentiment. Journal of Financial Economics, Vol. 49. No. 3. 307-343. o. http://dx.doi.org/10.1016/s0304405x(98)00027-0.

Barberis, N.-Thaler, R. [2003]: A Survey of Behavioral Finance. Megjelent: Handbook of the Economics of Finance, Vol. 1. 18. fejezet, 1053-1128. o. Financial Markets and Asset Pricing. http://dx.doi.org/10.1016/s1574-0102(03)01027-6.

Benartzi, S. [2001]: Excessive Extrapolation and the Allocation of 401(k) Accounts to Company Stock. Journal of Finance, Vol. 56. No. 5. 1747-1764. o. http://dx.doi.org/10.1111/00221082.00388 .

Camerer, C.-Issacharoff, S.-Loewenstein, S.-ODonoghue, T.-Rabin, M. [2003]: Regulation for Conservatives: Behavioral Economics and the Case for Asymmetric Paternalism. University of Pennsylvania Law Review, Vol. 151. No. 3. 1211-1254. o. http://dx.doi. org/10.2307/3312889.

Carhart, M. M. [1997]: On Persistence in Mutual Fund Performance. The Journal of Finance, Vol. 52. No. 1. 57-82. o. .http://dx.doi.org/10.2307/2329556.

Chan, K. C. [1988]: On the Contrarian Investment Strategy. Journal of Business, Vol. 61. No. 2. 147-163. o. http://dx.doi.org/10.1086/296425.

Chen, C. R.-Sauer, D. A. [1997]: Is Stock Market Overreaction Persistent Over Time? Journal of Business Finance and Accounting, Vol. 24. No. 1. 51-66. o. http://dx.doi. org/10.1111/1468-5957.00094.

Chopra, N.-Lakonishok, J.-Ritter, J. R. [1992]: Measuring Abnormal Performance. Do Stocks Overreact? Journal of Financial Economics, Vol. 31. No. 2. 235-268. o. http://dx.doi. org/10.1016/0304-405x(92)90005-i.

De Bondt, W. F. M.-Thaler, H. R. [1985]: Does the Stock Market Overreact? Journal of Finance, 40. No. 3. 793-805. o. http://dx.doi.org/10.1111/j.1540-6261.1985.tb05004.x.

De Bondt, W. F. M.-Thaler, H. R. [1987]: Further Evidence on Investor Overreaction and Stock Market Seasonality. Journal of Finance, 42. No. 3. 557-581. o. http://dx.doi. org/10.1111/j.1540-6261.1987.tb04569.x.

Della Vigna, S. [2009]: Psychology and Economics: Evidence from The Field. Journal of Economic Literature, Vol. 47. No. 2. 315-372. o. http://dx.doi.org/10.1257/jel.47.2.315.

FAMA, E. F. [1970]: Efficient Capital Markets. A Review of Theory and Empirical Work. Journal of Finance, Vol. 25. No. 2. 383-417. o. http://dx.doi.org/10.2307/2325486.

FAmA, E. F. [1991]: Efficient Capital Markets II. Journal of Finance, Vol. 46. No. 5. 1575-1617. o. http://dx.doi.org/10.2307/2328565.

FAmA, E. F. [1998]: Market Efficiency, Long-Term Returns, and Behavioral Finance. Journal of Financial Economics, Vol. 49. No. 3. 283-306. o. http://dx.doi.org/10.1016/s0304405x(98)00026-9.

FAma, E. F.-French, K. R. [1996]: Multifactor Explanations of Asset Pricing Anomalies. Journal of Finance, Vol. 51. No. 1. 55-84. o. http://dx.doi.org/10.2307/2329302.

He, X. Z.-LI, K. [2007]: Profitability of Contrarian and Momentum Strategies and Market Stability. Finance Discipline Group, UTS Business School, University of Technology, Sydney.

Hong, H.-Stein, J. [1999]: A Unified Theory of Underreaction, Momentum Trading, and Overreaction in Asset Markets. Journal of Finance, Vol. 54. No. 6. 2143-2184. o. http:// dx.doi.org/10.1111/0022-1082.00184.

Hunyadi LÁszló-Mundruczó György-Vita LÁszló [2001]: Statisztika. Aula Kiadó, Budapest. 
Jegadeesh, N.-Titman, S. [1993]: Returns to Buying Winners and Selling Losers: Implications for Stock Market Efficiency. Journal of Finance, Vol. 48. No. 1. 65-91. o. http://dx.doi. org/10.1111/j.1540-6261.1993.tb04702.x.

КомÁromi György [2002]: A hatékony piacok elméletének elméleti és gyakorlati relevanciája. Közgazdasági Szemle, 49. évf. 5. sz. 377-395. o.

LUKÁcs PÉTER [2003]: Értékpapírok hozamának eloszlása és a tőzsdei kapitalizáció. Szigma, 34. évf. 1-2. sz. 31-43. o.

Marton Rita [2001]: A magyar tőkepiac hatékonyságának vizsgálata. Bankszemle, 45. évf. 4-5. sz. 72-87. o.

McLean, R. D. [2010]: Idiosyncratic Risk, Long-term Reversal, and Momentum. Journal of Financial and Quantitative Analysis, Vol. 45. No. 4. 883-906. o. http://dx.doi.org/10.1017/ s0022109010000311.

Molnár MÁrK ANDrás [2006a]: A magyar tőkepiac vizsgálata pénzügyi viselkedéstani módszerekkel. Doktori értekezés, Budapesti Corvinus Egyetem, Budapest.

Molnár MÁrk András [2006b]: A budapesti értéktőzsde hatékonysága. Hitelintézeti Szemle, 5. évf. 5-6. sz. 28-35. o.

Nagy BÁlint-Ulbert József [2007]: Tőkepiaci anomáliák. Statisztikai Szemle, 85. évf. 12. sz. 1014-1032. o.

RABIN, M. [2002]: Inference by Believers in the Law of Small Numbers. Quarterly Journal of Economics, Vol. 117. No. 3. 775-816. o. http://dx.doi.org/10.1162/003355302760193896.

RAPPAI GÁBOR [1995]: A hatékony tőkepiacok elmélete a gyakorlatban. Megjelent: Studio Oeconomica jubileumi tanulmánykötet, Janus Pannonius Tudományegyetem, Közgazdaságtudományi Kar, Pécs.

Rouwenhorst, G. K. [1998]: International Momentum Strategies. The Journal of Finance, Vol. 53. No. 1. 267-284. o. http://dx.doi.org/10.1111/0022-1082.95722.

SHILleR, R. [2003]: From Efficient Market Theory to Behavioral Finance. Journal of Economic Perspectives, Vol. 17. No. 1. 83-104. o. http://dx.doi.org/10.1257/089533003321164967.

Simon, S. [2002]: Momentum Effects and Mean Reversion in Real Estate Securities. Journal of Real Estate Research, Vol. 23. No. 1-2. 47-64. o.

Vayanos, D.-Woolley, P. [2013]: An Institutional Theory of Momentum and Reversal. Review of Financial Studies, Vol. 26. No. 5. 1087-1145. o. http:/dx.doi.org/10.1093/ rfs/hht014.

Zarovin, P. [1989]: Does the Stock Market Overreact to Corporate Earnings Information? The Journal of Finance, Vol. 44. No. 5. 1385-1399. o. http://dx.doi.org/10.1111/j.15406261.1989.tb02660.x. 


\section{Függelék}

F1. táblázat

Az egyes részvények (részvénykódok) abnormális hozamainak Jarque-Bera-próbájához tartozó p-értékek

\begin{tabular}{lclll}
\hline Részvény & $p$-érték & & Részvény & $p$-érték \\
\cline { 1 - 2 } ANTENNA & 0,0000 & & IEB & 0,0000 \\
ANY & 0,7447 & & MOL & 0,0000 \\
BCHEM & 0,0342 & & MTELEKOM & 0,0608 \\
CSOPAK & 0,0000 & & ORC & 0,0010 \\
DANUBIUS & 0,8303 & OTP & 0,0000 \\
DEMASZ & 0,0372 & PANNERGY & 0,0057 \\
EGIS & 0,0000 & PICK & 0,0802 \\
ESTAR & 0,0000 & PRIMAGAZ & 0,0000 \\
ESTMEDIA & 0,0000 & RABA & 0,0001 \\
FHB & 0,0000 & RICHTER & 0,6353 \\
GLOBUS & 0,0000 & SYNERGON & 0,0000 \\
GRABO & 0,0002 & TVK & 0,0000 \\
GRAPHI & 0,0013 & ZKERAMIA & 0,0000 \\
GSPARK & 0,2212 & ZWACK & 0,0000 \\
\hline
\end{tabular}

Forrás: saját számítás és szerkesztés. 


\section{F1. ábra}

A túl- és alulteljesítő portfóliók a tesztperiódusban, különböző hosszúságú megfigyelési periódusok alapján, az abnormális hozam CAPM-alapú megközelítésével számolva
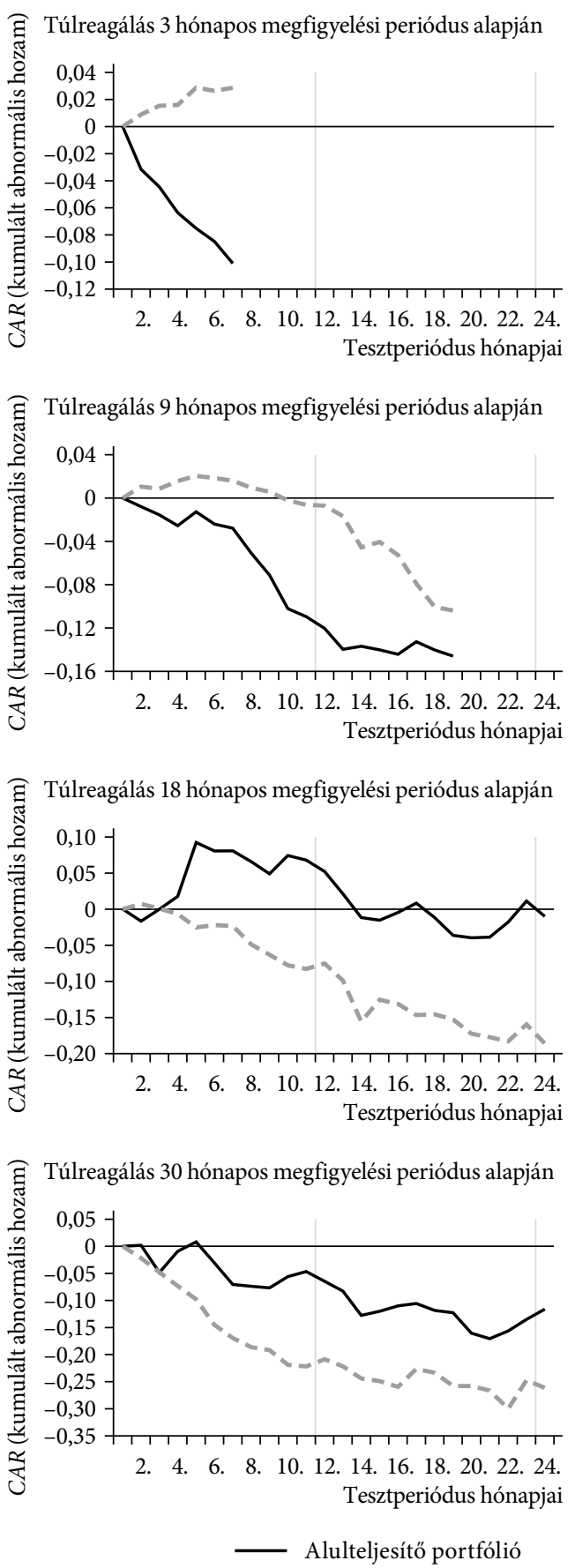

Túlreagálás 6 hónapos megfigyelési periódus alapján

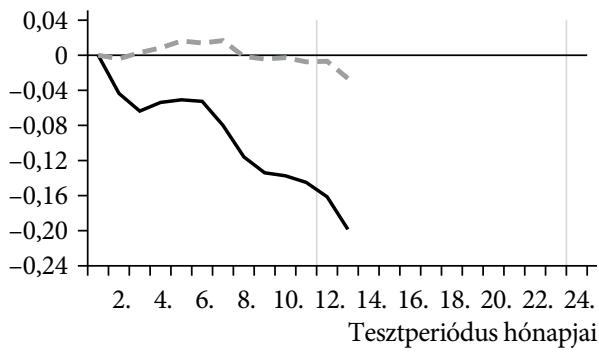

Túlreagálás 12 hónapos megfigyelési periódus alapján

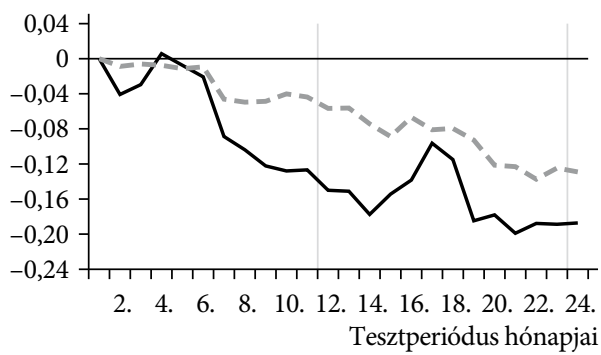

Túlreagálás 24 hónapos megfigyelési periódus alapján

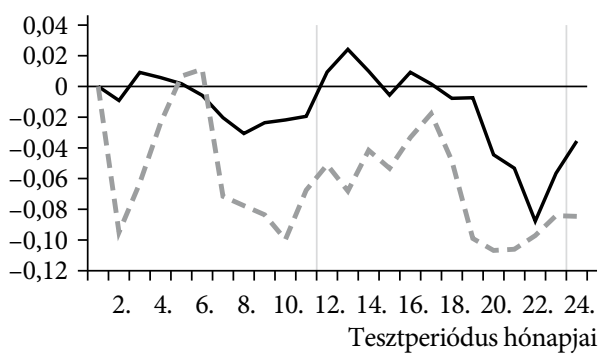

Túlreagálás 36 hónapos megfigyelési periódus alapján

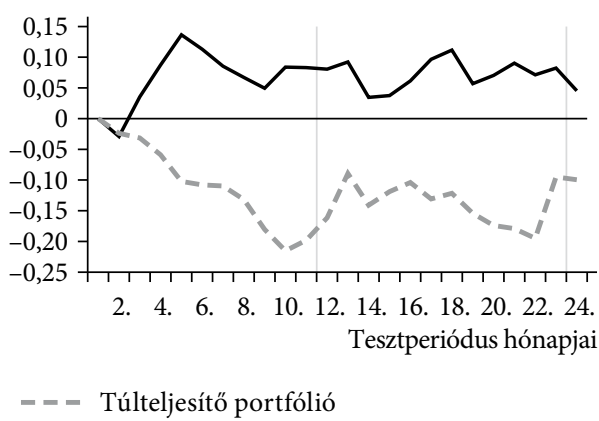

Forrás: saját számítás és szerkesztés. 